\title{
THE JERRY BUILDER
}

\section{CONSIDERED IN RELATION TO THE HOUSING OF THE POOR.}

Bx E. GWYNN, M.D.,

Medical Offeer of Health of Hampstead.

THe question of providing healthy and reasonable household accommodation for the very poor is not infrequently approached as if it were a discovery of modern date. As a matter of fact, wherever circumstances have led to the aggregation of vast numbers of the community on a limited area, particularly in the great cities of antiquity, both the want of house shelter, and overcrowding, with the consequent danger to public health, have been recognised, and in some instances recorded.

It has been calculated that Nineveh contained at least a milliom inhabitants, and that the population of Babylon in the days of its empire was not less than two millions, many of the inhabitants being captives or slaves huddled together in barrack-like shelters at night, for the security of their owners. The elimate, no doubt, obviated some of the consequences of this overcrowding, but the mortality was high, the death of slaves being little regarded by their owners, except in its pecuniary aspect, and accepted by the victims themselves as a welcome eseape from lives of intolerable burden.

The population of Rome at the height of its power probably numbered at least from two to three millions, including a vast slave population for the most part miserably housed; nor was the treatment of eaptives and slaves less harsh and cruel in Carthage.

In the Dark Ages and in mediæval times, in periods of war, and to obtain security from outrage, the overcrowding of the walled cities often became excessive, and was attended by an appalling mortality, whilst in more recent history the crowding of the Ghettos of continental cities has continued almost up to recent dates.

The phenomenal growth, not only of London, but of most of the. great capitals of Europe, is a feature of the last fifty years, and is the natural result of the spread of civilization, of education, and of culture. London has increased its population during the last fifty years by $2,500,000$ souls. Year by year some 60,000 people are added to its numbers, chiefly by immigration from the country. 
Misled by the enormous rateable value of London, it is not generally recognised that it is to a great extent a city of the poor, or that it is inhabited by a majority of people divided by one or two weeks' wages from starvation. It is, however, only necessary to traverse a district proceeding from the north-west to furthest east on the one side, or from London Bridge to furthest south-east on the other side, to find mile after mile of streets inhabited by a population living in groups of families in the class of houses styled "tenement" houses for want of a better name. It has. been stated, apparently on good authority, that one may walk through three or four miles of streets in certain districts without finding a householder prosperous enough to command the services of a single domestic.

The awakening of the public conscience to the great question of the housing of the very poor has been slowly accomplished during the last fifty years by the earnest efforts of a few devoted men. Royal Commissioners have reported on the question, congresses and conferences discussed it, but the problem of providing healthy and cheap dwellings for the very poor appears at the present moment as far from solution as before. The growth of the poorer side of London has for some time been watched with anxiety by statesmen and philanthropists, but the very rapidity and magnitude. of the movement has to a great extent paralyzed their action.

- Parliament, uneasy at the revelations of the scandalous overcrowding made from time to time by coroners' inquests, by police reports, by the inspection of the officers of sanitary bodies, and by newspaper articles, has made several attempts to find a remedy for this state of things. The numerous Acts of Parliament: dealing with the housing of the working classes passed during the last half of the century, which were in 1890 consolidated into the Housing of the Working Classes Act, fell into three groups. The first empowered local authorities to provide lodging-houses for the working classes, and under them a local authority could provide a cottage and a garden of not more than half an acre, of which the yearly value was not to exceed $£ 3$. The second group dealt with houses in such a state as to be dangerous to health and unfit for human habitation, and under their provisions many hundreds of insanitary houses have been pulled down on the certificates of medical officers of health. The third group enables the local authority to deal with unhealthy areas.

The timidity and hesitation of the authorities entrusted with the carrying out of these Acts is in striking contrast with the vigour displayed by another London Board drawing its authority from the 
same source. In the matter of infectious fevers it has been found possible, in London at least, to treat disease with a firm hand. It may be said that the method is expensive, but the results are eminently satisfactory. Under the management of the Asylums Board small-pox has been almost stamped out, and the death-rate from scarlet fever lowered to a minimum.

The question naturally arises as to what constitutes overerowding in the absence of any legal definition of the term. People sometimes write to sanitary authorities that such and such a house is overcrowded simply because it contains forty or fifty inhabitants, but upon measurements of rooms and calculations of cubical airspace being made, it is often found that there is no evidence to support the allegation. The need for caution is obvious, for should two convictions for overcrowding a house, or even part of a house, be obtained within three months, the sanitary authority may apply to the court to order the house to be closed for such a period as the court may deem necessary.

The usual standard adopted by sanitary authorities is that of 300 cubic feet for every adult, and half that space for a child under ten or twelve years of age. When rooms are oceupied as living. rooms as well as bedrooms, the standard is raised to 400 feet. In determining overerowding, facilities for ventilation and the presence of furniture have to be taken into consideration. These foregoing requirements are taken from the Model Bye-laws of the Local Government Board, which are generally adopted by the local authorities when framing bye-laws for the regulation of tenement houses. Attempts to raise the standard in all cases to 400 feet have not always met with the sanction of the Local Government Board.

It is not always easy to arrive at the truth respecting overcrowding. The questions asked by the sanitary officers in the daytime, and answered with apparent frankness, are not always to be relied on. The facts revealed by a night inspection of the rooms are often far different. The medical officer of health of a West End parish recently reported that, on the occasion of an inspection conducted with the assistance of the police in the early morning, before the people had left their beds, five adult females were found in a room having a cubic capacity of 1,000 feet only, of whom two were found hidden under the bed. In another house five adults and two children were found in a room the air-space of which was only 1,650 feet. In this case also two young women had concealed themselves under the bed.

The difficulty experienced by persons with large families in 
obtaining accommodation is enhanced by the reluctance of landlords, with the fear of the sanitary inspector before them, to take them in. The more unscrupulous frequently resort to the following trick: They answer the usual inquiries when seeking lodgings by declaring that they have only two children, when as a matter of fact they may have five or six. In due course they take possession of their rooms accompanied by the two children mentioned, the remainder of the family having been left with some relative or neighbour, to be taken into the new home a few days later. If overcrowding results the landlord becomes liable. He must give notice to quit, perhaps has to apply to a magistrate for an ejectment order, and may not receive rent during the time the notice lasts.

Let us look for a moment at the classes most needing help in respect of house accommodation. It may be presumed, on the one hand, that artisans and others with wages of from $24 \mathrm{~s}$. to 30 s. per week are able to command the necessary air-space for their families at the current rents. On the other hand, it is not the object of this article to consider the ease of the lowest stratum, comprising the homeless loafers, casuals, etc., for it may be open to question how far it becomes the duty of the industrious and careful part of society to provide house-room for the idle and vicious. But the class in need of assistance is that of the poor but industrious people, whose earnings, either intermittent or regular, range from $18 \mathrm{~s}$. to $22 \mathrm{~s}$. per week. It has been calculated that this important class numbers in London alone over 600,000 souls. How, then, is assistance to be afforded to these people who stand in most need of help, and with whom the greatest tendency to overcrowding exists? There are those who, like Sir Charles Sullivan, advocate the production and letting of rooms by municipal bodies at 1s. per week. Sir Charles does not, however, state what the cubical capacity of these rooms is to be, and that, after all, is the essence of the matter if overcrowding is to be avoided.

It would not be diffeult to show that a comparison instituted between the rent charged for cubical air-space by various bodies, such as the London County Council, various charitable bodies, and others, would go in favour of the jerry builder. A study of the prices of rooms charged by the various bodies already named will show that with few exceptions $2 \mathrm{~s}$. per room is the lowest rent at which accommodation can be obtained. From the table it will be seen that 400 feet of cubical space-that is, accommodation for one adult or two children-will cost 1s. or more in the working-class dwellings; from $9 \mathrm{~d}$. to $1 \mathrm{~s}$. in the Peabody Buildings; 
will range from 1s. $3 \mathrm{~d}$. to $1 \mathrm{~s} .7 \mathrm{~d}$. in the rooms erected by the Society for Improving the Dwellings of the Poor; but will cost in jerry-built houses in Netherwood Street, Kilburn, from $7 \mathrm{~d}$. to 10d., according to situation of rooms; from 10d. to 1s. in the busy Fleet Road, Hampstead; and from 8d. to $8 \frac{1}{2} d$. in decayed old houses in New End, Hampstead. The charge for air-space is invariably higher in single rooms than in sets of two or three rooms, and the position as to floor and outlook also affects the market value. Hampstead possesses several blocks of model

Value of 400 Cubic Feet Air-space in Buildings.

\begin{tabular}{|c|c|c|c|c|}
\hline & $\begin{array}{l}\text { Single } \\
\text { Rooms. }\end{array}$ & Two Rooms. & $\begin{array}{l}\text { Three } \\
\text { Rooms. }\end{array}$ & $\begin{array}{l}\text { Four or } \\
\text { more } \\
\text { Rooms. }\end{array}$ \\
\hline 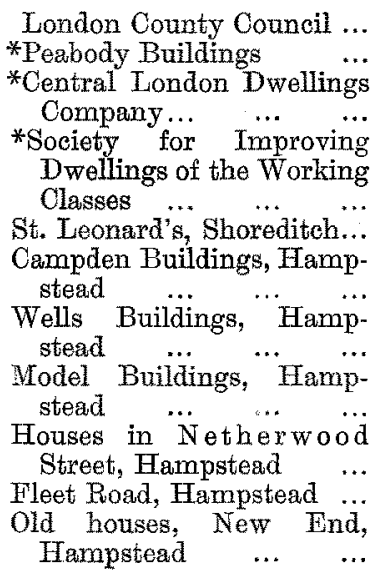 & $\begin{array}{l}\ldots \\
\ldots \\
1 \mathrm{~s} . \\
1 \mathrm{~s} .\end{array}$ & $\begin{array}{c}\text { 1s. } 4 \mathrm{~d} \text {. to } 1 \mathrm{~s} .7 \mathrm{~d} \text {. } \\
\text { 1s. } 7 \mathrm{~d} \text {. } \\
\begin{array}{c}10 \frac{\mathrm{d}}{2} \mathrm{~d} . \text { to } 1 \mathrm{~s} .1 \mathrm{~d} . \\
10 \mathrm{~d} . \\
\ldots \\
7 \mathrm{~d} \text { to } 10 \mathrm{~d} . \\
10 \mathrm{~d} \text {. to } 1 \mathrm{~s} . \\
8 \frac{1}{2} \mathrm{~d} .\end{array}\end{array}$ & 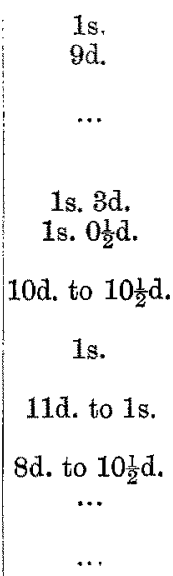 & $\begin{array}{c}\ldots \\
\ldots \\
\ldots \\
1 s . \\
10 d .\end{array}$ \\
\hline
\end{tabular}

dwellings, some of which have been erected by a charity known as the Wells and Campden Charity, and others by private enterprise. In the former buildings, which are by no means let at their market value, the rent for 400 feet of cubical air-space ranges from $10 \mathrm{~d}$. in two and three roomed tenements to $1 \mathrm{~s}$. for single rooms. In the working-class dwellings built by the Vestry of Shorediteh, and opened by Lord Rosebery in November, 1899, the value of the 400 feet of air-space ranges from 1s. $0 \frac{1}{2} d$. for sets of three rooms to $1 \mathrm{~s}$. $7 \mathrm{~d}$. for two rooms. In this case also the committee stated that they could have obtained higher rentals if they had decided to do so. It is an incontestable fact that in all instances in which public bodies have erected dwellings for the

* Buildings in St. Giles's Parish. 
poor, the class for whom they were provided do not oceupy them. And the reason is not far to seek. Well built, well arranged, with separate closet and sink accommodation, they are eagerly taken possession of by the more intelligent of the artisan classes, and, commanding as they do nearly the market value, they become quite out of the reach of the very poor, the class for which it is presumed they were intended. Moreover, the collection of the rents of these dwellings, owned and managed by committees, must be necessarily delegated to an agent or manager, who will naturally select the most respectable applicants-those, indeed, who will be punctual in payment of rent, and not give rise to trouble by drunkenness or disorderly conduct. Should such gain entrance, they will be speedily eliminated, and so it comes to pass that, by a sort of natural law, the best of these tenements come into the hands of those who best, by their intelligence, know how to look after their own interests.

It would therefore appear that cubical space in County Council dwellings, Peabody Buildings, Campden Buildings, and others, is worth from 10d. to 1s. $7 \mathrm{~d}$., but can be had in jerry-built houses from $7 \mathrm{~d}$. to 1s., according to the situation of the rooms. The case becomes still more striking when the decisions of the various bodies not to allow more than a fixed number of adults and children in their rooms is taken into account, for there is no such restriction in tenement houses. The labourer with a large family is naturally driven to take advantage to its fullest extent of the aircapacity afforded him. To accommodate his family, a labourer with five or six children-and this is no uneommon ease-is by stress of circumstances, such as not being able to afford more than $5 \mathrm{~s} .6 \mathrm{~d}$. out of a wage of $23 \mathrm{~s}$., forced to seek house-room in a tenement house, often of bad construction, where he can get two large basement rooms, those being the cheapest.

The London County Council in ten years has succeeded in housing about 7,000 people, but it must be remembered that these people merely take the place of the larger number evicted for the demolition of insanitary areas, and the forming of new streets, ete. The Peabody and other London Building Companies for Housing the Working Classes have probably provided accommodation for another quarter of a million during the last thirty years. But the tendency of all these dwellings, let at rents which only the well-to-do artisans can afford, has been to draw down to them the better classes rather than to assist the poorer class, for whom they were intended. They have, in a word, only supplied good dwellings in the place of bad, and have not even kept pace with the increasing 
demands caused by the annual additions to the population of London. As a remedy for the overcrowding of the very poor, their effect is very slight. In other words, whilst the various bodies already named have, with all their resources, during the past decades provided house accommodation for thousands, the jerry builder has succeeded in housing tens of thousands.

This result has been attained by the much cheaper rate at which cubical air-space per person can be furnished by the jerry builder, and to this extent the system must be admitted to have the virtue of its defects.

The cost for each person housed by the various public bodies for building alone, without the value of the land upon which the buildings stand, varies from $\& 45$ to $\& 100$. The London County Council's buildings work out at about $\$ 60$ per inhabitant, and the Peabody Buildings over $\$ 90$. In the case of jerry-built houses the cost comes out nearer $\$ 15$ to $\$ 20$. Taking the lower cost of building into account, whilst the County Council can barely pay $\mathbf{3}$ per cent. on its outlay, and the Peabody $2 \frac{1}{2}$ per cent., the jerry builder is able to extract over 6 per cent. from his unfortunate tenants. In the case of the Artisans ${ }^{3}$ Dwellings Companies and others who have formerly been able to pay 5 per cent. on their capital, it must be remembered that their building sites were carefully selected, that they built when labour was much cheaper than it is at present, and that they obtain the highest rents the neighbourhood will command. Further, it follows that the higher the rent placed on sets of rooms, the less fear there will be of overcrowding: for these rooms can only come into the possession of those who, from their good income, can afford sufficient accommodation. These buildings, as has been stated, largely replace those pulled down by the clearance made in the first instance, and although instructions are generally given to keep a register of the inhabitants displaced, and to give them the preference as tenants for the new buildings, the additional rent on the one hand, and restrictions as to numbers on the other, compel the former inhabitants of the district to further congest the immediate neighbourhood, or to seek in the suburbs the accommodation denied to them in town.

It must not for a moment be supposed that any medical officer of health would advocate the occupation of rooms to their full legal capacity, or question that the Local Government Board is right in restricting the number of persons allowed to occupy each room, and that the County Council is wrong in placing a rent on their new rooms equivalent to that current in the neighbourhood. But it will be seen that these new buildings, whilst setting forth a fit 
and proper example of what sanitary buildings should be for the working classes, do little or nothing to tonch the subject in hand, viz., to provide decent accommodation, which is to be free from overcrowding, for the very poor.

If we assume that there are at the present time from 600,000 to 900,000 persons needing assistance in this direction, who are at present paying the highest rent their wages will allow, a little reflection will show how impossible it is for any public body to furnish house-room at reduced rents, except at enormous charges to the ratepayers. To provide accommodation for half that number by a ring of barrack-like buildings round London would require a capital expenditure of from 25 to 50 million pounds. Now, the County Council, letting their rooms at current prices, viz., 2s. per room, barely secure a return of 3 per cent. If the rooms to be erected were let at 1s. per room, there would probably be a charge of from $\$ 300,000$ to $\$ 500,000$ on the rates. It may be said that by relieving pressure the rents of the old tenement houses would fall. That would entail a loss on the local rates, and inflict a heavy fine on property owners by the reduction in the market value of their houses. Moreover, unless undertaken on a colossal scale, the buildings to be thus erected would scarcely do more than meet the demands of the 10,000 poorer classes who annually seek the shelter of the Metropolis.

We have seen that the jerry builder has, more swo, been able to supply the demand for accommodation by the working classes, and that for the next ten or twenty years at least there is little prospect of successful competition against him; but the question naturally arises, Are there no means by which the evils engendered by his system may be combated? For in his case it may with truth be said: "The evil that men do lives after them."

The evolution of the jerry-built house appears to be somewhat as follows: Some green fields, or some mansion with a few acres of pleasure or garden ground, conveniently situated in the suburbs, are advertised to be sold, or let on building leases. Timber is forthwith cut down, roads formed, and sewers built; plans are prepared by which the ground is cut up into plots containing a few feet of frontage and a greater number of feet for depth. These plots, if not sold, are let at a ground-rent of so many pounds each, the lessee undertaking to put a house of specified value upon it. By these means it is intended that a field, which at the time of letting brings in a few shillings per annum as grazing ground, shall, when covered with houses, bring in as many pounds, and that, moreover, the houses erected thereon shall revert to the ground landlord at 
the termination of the lease. But to get the houses built something more is needed. The capitalist, often the owner of the land, now comes forward with loans, to enable a class of small builders to undertake the work. These builders, for the most part men with little or no means, but with a certain knowledge and experience, have to build the houses and to support themselves and families during the period in which the loans can be made to last. A surveyor is appointed to protect the advancer of loans, and if he prove faithful to his employer the brick, lime and timber merchants, and others, will probably suffer by the bankruptcy of the builder. But if the builder is not to fail, it follows that he must go to the cheapest market for his materials. His bricks will be porous, his timber "shaky," his mortar deficient in lime, his plaster destitute of hair, his woodwork and joinery of the most unsatisfactory kind, and his sanitary appliances of the cheapest quality. The drainage, supposed for the most part to have been supervised by the sanitary officials, will often be found to be defective, and although the introduction during the last few years of the water test has recently secured an improvement in this respect, it may be said, without much fear of contradiction, that in a great part of London the jerry builder has been content with clay-jointed drains, which are now leaky.

The houses thus erected will, if possible, be sold, often at a very small margin of profit, in order to obtain a quick return of capital, with a view to further operations, or, failing sale, will be let at a cheap rate to start them. As a result, whatever may have happened to the builder, at least the grand object of the whole transaction, namely, the creation of a valuable ground-rent, will have been obtained. It not infrequently happens that an artisan or clerk will be tempted to invest his savings in one of these houses, either for his own occupation or for letting, it may be, by the aid of one or other of the benevolent or building societies. He too often finds, either on the occurrence of illness or upon complaint from a tenant, that after the visit of the sanitary inspector he is saddled with the costs of redrainage, a veritable fine, in fact, of $£ 40$ or $£ 50$, which he is quite unable to meet.

It is said that Madame de Pompadour exclaimed, Après nous le déluge. Well might the jerry builder repeat the remark-a deluge, truly, of sanitary notices from the authorities to repair the original defects in drainage, obviate dampness, atc. More than 50,000 notices for repair to drains and other sanitary matters are annually served for the abatement of nuisances due in a great measure to original defective construction. 
The action of the district surveyor, in preventing the use of inferior materials, is necessarily much hampered by the fact that his only remedy in disputed eases is a summons before a police magistrate. It is comparatively easy for the attacked party to bring "expert" evidence into court in support of the quality of the materials he is using. The magistrate, unable to decide between the conflicting experts, too often declines to inflict a fine, the district surveyor becomes discouraged, and is naturally inclined to pass work that is unsatisfactory.

Many of the jerry-built terraces and roads of houses were originally intended for the occupation of better classes, such as clerks, etc., than now occupy them; but, not having for some reason or other been occupied by those classes, the houses have fallen into the hands of the working classes, and are now let out in tenements and rooms. Planned originally for oceupation by one family, they are very badly adapted for working people, especially in regard to kitchen, scullery, and closet accommodation. The superior height of the rooms in these houses to that of buildings erected by public bodies, by giving a greater air-capacity, enables poor families to get more accommodation without legal overerowding, in many instances at the expense of decency.

The crowded occupants of tenement dwellings may be divided into two elasses-viz., those who as soon as the opportunity oceurs secure more ample aceommodation, and those who, when their circumstances improve, spend their extra money in the winter in stimulants, and in the summer in excursions. The latter are too often open to the reproach that they prefer dirty and ill-kept houses, where they are surrounded by people of their own way of thinking, and where their peculiar habits cease to come under any unpleasant observation.

The wonderful and almost invincible patience of the poor to their lot makes them too often tolerate circumstances which should and could be altered by a wider knowledge on their part of sanitary laws. The mephitic air of rooms tenanted day and night, the foul unwashed bedding and elothing, are matters which could be remedied by the opening of windows and the use of soap and water. The dislike of fresh air is excused on the ground of the small fire which can be afforded, the demand for warmth being often greater even than for food. Tenants are sometimes anxious to coneeal insanitary conditions, because they know from experience that all costs for the sanitary improvements will ultimately be exacted in increased rent, if, indeed, they be not ejected for complaining. They have yet to learn that an extra $6 \mathrm{~d}$. a week in rent 
is less costly in the long-run than illness or death arising from the insanitary conditions of the home.

It would seem, therefore, that attempts to take the housing of the poor out of the hands of the speculative builder on any large scale are not likely to meet with success. The difficulties are so numerous, and the interference with economic laws so serious, that a little reflection will show that any gigantic scheme for relieving the evils of overerowding by State-aided building schemes may end in Socialism and exceed discretion.

Assuming that the jerry builder is for the time being master of the situation, how may "this necessary evil" be brought more into harmony with present opinions?

As the jerry builder is the creation of the "terminable ground lease" system, the first step to be taken to improve him out of existence is to provide for the enfranchisement of ground-rents.

Legislation is required-

1. (a) To provide for the enfranchisement of existing ground-rents on equitable terms.

(b) To provide, with a view of encouraging freeholds, that in the case of all houses erected after the year (say) 1900 the ground-rents should be purchasable at (say) fifteen years' purchase.

2. To enable the London County Council to purchase land beyond the county boundaries for the purpose of erecting working men's dwellings.

3. To extend the powers of the district surveyors.

Further amelioration could be secured-

1. By obtaining from the London County Couneil the longpromised regulations as to drainage.

2. By the removal, where possible, of factories and workshops to extra-Metropolitan districts.

3. By affording every facility for easy and cheap access to the suburbs by means of railways, steam and electric trams, etc.

4. By encouraging public bodies, City companies, and philanthropists to buy estates in the districts bordering on London for the purpose of erecting working men's dwellings, and to erect thereon two houses of two stories each with garden as models to be followed by others.

The obvious advantages of encouraging the working man to leave the centre of London and to bring up his family in the purer air of 
the country are apparent to all, and should be encouraged to the utmost. That he is eager to take advantage when the opportunity is afforded him the following figures will show.

The county of London is surrounded by forty-five distriets, of which twenty-five are in immediate contact with it. If the population of these parishes as they existed in 1851 be contrasted with the population in 1891 at the last census, very striking results will be obtained.* Wherever there has been ample and free railway communication, supplemented in many cases by tramways, enormous developments of the population have taken place. Thus, the population of Hornsey has increased from 7,185 to 61,197; that of Tottenham from 9,120 to 97,174 ; that of Walthamstow from 4,959 to 46,340 ; that of Leyton from 3,901 to 43,906 ; and in the most remarkable case of all, that of West Ham from 18,817 to 204,906. The facilities afforded by the Great Eastern and Great Northern Railways have led to these results. By contrast we may take the parishes served by the Midland, which show very little progress. The population of Hendon has increased from 3,333 to only 15,843 , and that of Finchley from 4,120 to 16,647 . In marked contrast with these stands Willesden, with a service of three important lines, the population of which has increased from 2,939 to 61,265 . In the west the populations of Acton and Chiswick, served by the North-Western, Great Western, and North London, have increased from 2,582 to 24,206 and 6,303 to 21,963 respectively. The most striking example on the south side is Croydon, enjoying an ample service of trains by the Brighton and South-Eastern Companies, where the population has increased from 20,081 to 102,695 .

One great cause of the dirty and otherwise insanitary condition of much of the jerry-built tenement property in London is the indifference of the owners, who often know little, and care less, as to what is going on, provided a certain rent is obtainable. There are other owners, frequently absentees, who wish that every facility should be given to their tenants, yet find it more convenient to transfer the trouble of looking after the property to some agent who does not participate in that sentiment. The case is still worse when property of this class gets into the hands of the legal trustees, or when the property has been foreclosed. All remonstrances are met with the cry for time, "as the property will shortly be sold," and months drag on before the necessary repairs can be obtained.

The habits of the poor themselves are often incredibly dirty and

* The map which accompanies this communication was prepared by Mr. H. Sharpe, late Chairman of the Public Health Cormmittee of the Vestry of Hampstead. 


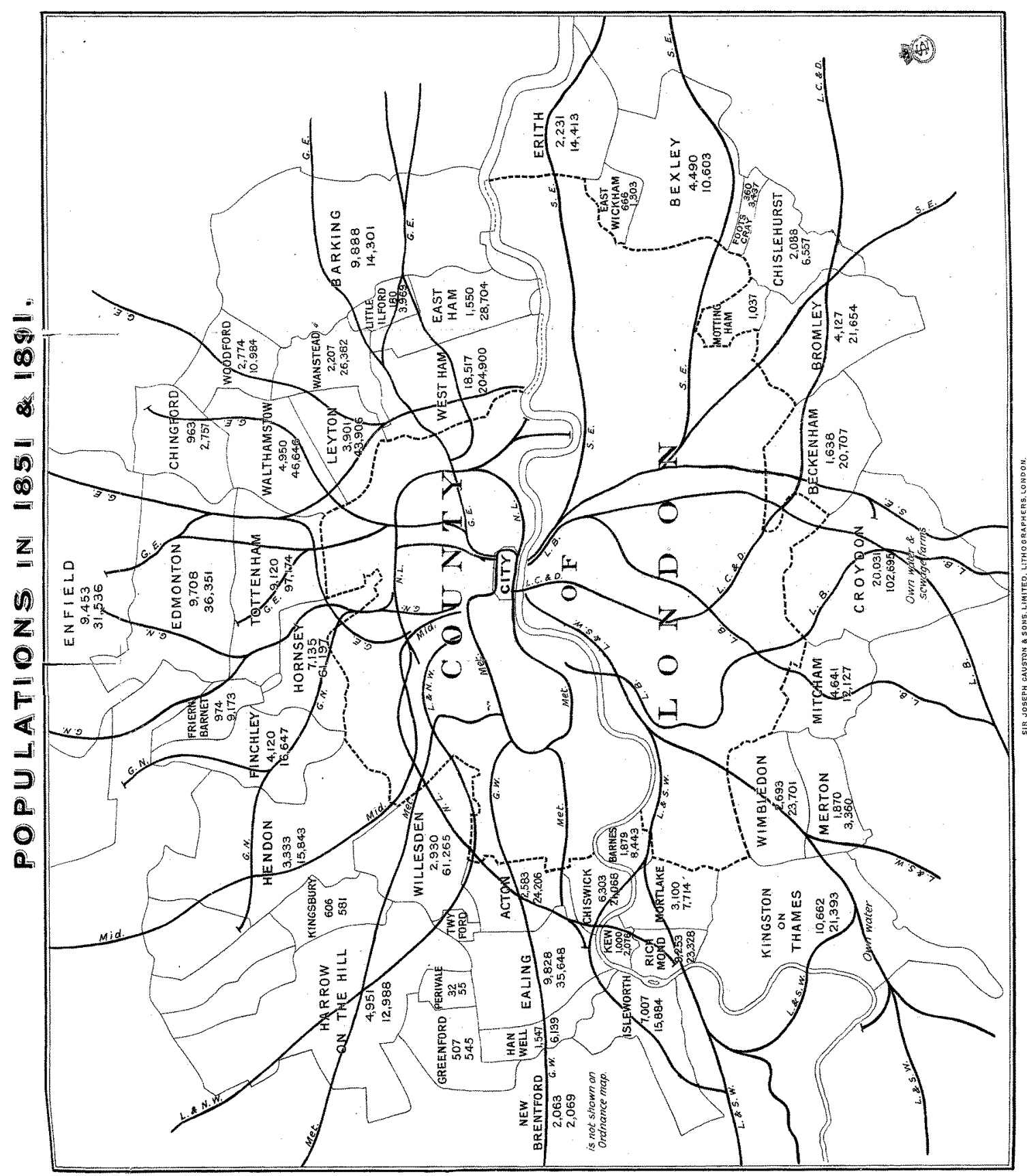


unsatisfactory, and baffle attempts to reform them. An inspector recently ordered a heap of insanitary rubbish to be removed from a yard; on his visit next day ho found the heap had been got rid of by the simple expedient of pitching it over the neighbour's wall. Perhaps the system inaugurated by Miss Octavia Hill offers the best instance of the way in which tenement property should be handled by personal supervision. If many of those who are so ready to oceupy platforms and denounce the evils of the overcrowded poor would themselves, by purchasing and personally looking after some ten or a dozen tenement houses, look deeper into this difficult subject, we might at least hope that greater results might be obtained.

New Margarine Law in Belgium.-The date on which this law comes into force will not be later than January 1st next, and it enacts that-

The term "butter" is reserved for fat obtained from milk or cream by churning, with or without the addition of ferments, colouring matters, or salts. Other alimentary fats resembling butter in their external characters, such as appearance, consistency, colour, odour, taste, are termed margarine.

Mixtures of butter and margarine for sale are prohibited. Margarine for sale may not contain more than 10 per cent. of fat derived from milk. It must be mixed with substances which, while being inoffensive and incapable of altering its organoleptic characters, will facilitate its distinction from butter. Particulars of these substances will be given later in a royal decree.

Produce destined for direct export is exempted from these provisions if declared prior to manufacture.

Margarine must be delivered from a manufactory or wholesale dealer in vessels bearing the word "Margarine" on every face, in letters at least four-fifths of an inch high, with the name and address of the firm.

Butter and margarine may not be sold on the same premises, and butter merchants or producers may not keep margarine even for their personal consumption on premises where butter is sold.

All shops where margarine is sold, as well as vehicles serving for peddling margarine, must bear the words "Sale of margarine" in distinct type at least 8 inches high, and clear of all other inscriptions. In market-places margarine may only be sold at spots specifically indicated by the communal authority, and at least 25 yards from any butter-stall.

All vessels or wrappers in which margarine is sold must have the word "Margarine" in letters distinctly visible to the public, at least four-fifths of an inch high and clear of all other matters, as well as the name and address of the seller. If sold in blocks, these must be cubical in shape and marked in a similar manner.

Abnormal butter, i.e., butter of which the characteristics differ from those of most pure butter, without exhibiting clearly adulteration or serious alteration, may not be sold. A royal decree will specify the physical and chemical indications by which these characters may be recognised.-Food and Sanitation. 